\title{
Trace metal and aflatoxin concentrations in some processed cereal and root and tuber flour
}

\author{
Hayford Ofori ${ }^{*}$, Charles Tortoe, Paa Toah Akonor and Jonathan Ampah
}

\begin{abstract}
Background: Sweet potato, cocoyam, water yam, maize, millet, sorghum, and rice are major staple foods in Ghana. Flour from these roots and tubers and cereals are relatively cheaper, easy to produce and can be used in the manufacturing of wide range of products, including bread, cookies, meat pies, cake, chips and doughnut. However, due to the processing techniques used these flours may be contaminated with trace metals and aflatoxins. It was therefore necessary to determine the concentration of trace metal: $\mathrm{As}, \mathrm{Cu}, \mathrm{Fe}, \mathrm{Hg}, \mathrm{Pb}, \mathrm{Zn}$, and aflatoxin $\mathrm{B}_{1}, \mathrm{~B}_{2}, \mathrm{G}_{1}$, and $G_{2}$ in maize, sorghum, millet, rice, cocoyam, water yam and sweet potato flour samples used as composite flour for making bread and other pastries.

Results: The trace metal concentration of essential metals: $\mathrm{Cu}$, Fe and $\mathrm{Zn}$ in all the seven flour samples analyzed ranged from $0.03 \pm 0.01$ to $6.63 \pm 0.02,10.97 \pm 0.01$ to $201.40 \pm 0.14$, and $6.04 \pm 0.03$ to $34.36 \pm 0.06 \mathrm{mg} / \mathrm{Kg}$,

respectively. The maximum concentrations of toxic metals: $\mathrm{As}, \mathrm{Hg}$ and $\mathrm{Pb}$ determined in all the seven flour samples were $<0.01,<0.01$, and $0.05 \pm 0.01 \mathrm{mg} / \mathrm{Kg}$, respectively. Aflatoxin $B_{1}, B_{2}, G_{1}$, and $G_{2}$ were not detected in any of the samples.
\end{abstract}

Conclusion: The concentrations of $\mathrm{As}, \mathrm{Cu}, \mathrm{Hg}, \mathrm{Pb}$ and $\mathrm{Zn}$ determined in all seven flour samples were below the WHO set limits and therefore pose no health threat whiles Fe concentration in some flour samples was above the WHO set limit. Aflatoxin $B_{1}, B_{2}, G_{1}$, and $G_{2}$ were not detected in all flour samples and hence pose no health threat.

Keywords: Flour, Root and tubers, Cereals, Heavy metal, Aflatoxins, WHO

\section{Background}

Root and tubers as well as cereal are major staple foods in Ghana. They contribute significantly to the elimination of food insecurity in Ghana. Maize is a base for several food preparations in Ghana. Maize supply in Ghana has steadily been increasing over the past few years with the average supply at 1.5 million MT. In the northern Ghana, millet and sorghum are the main cereals produced and consumed, but maize becomes the substitute when millet and sorghum are not available (MoFA 2011). Sorghum together with millet and more recently maize is a fundamental crop for North-East Ghana farming systems. It is mainly cultivated by small farmers with average landholdings not more than 2 ha

\footnotetext{
* Correspondence: oforihayford@yahoo.com

Council for Scientific and Industrial Research-Food Research Institute, P.O. Box M 20, Accra, Ghana
}

(Kudadjie et al. 2004). Production of sorghum in Ghana between 2005 and 2010 ranged from 305,000 tons to 324,422 tons, respectively (FAO 2012). Beyond food security and provision of cash the value of sorghum is linked to the social context and religious ceremonies typical of Ghana rural areas. During these events the sorghum artisanal beer called pito is widely consumed. Sweet potato (Ipomoea batatas) is fast growing root crop that can be produced in all regions of Ghana. It matures within four months, and yields about 20-25 tons per hectare. Cocoyam (Colocasia esculenta and Xanthosona spp) is well adapted food crop across many agroecological zones of Sub-Saharan Africa. It is ranked third in importance, after cassava and yam among root and tuber crops cultivated and consumed in many West and Central Africa Countries (Onyeka 2014). Cocoyam is nutritionally superior to both cassava and yam in the possession of higher protein, mineral and vitamin contents 
as well as easily digestible starch. Africa in the last three decades has consistently accounted for an increasing percentage of global cocoyam production, which currently stands at about 10 million tons per annum (FAO 2012). From 2008 to 2012, Africa accounted for $74 \%$ of global cocoyam production with approximately $50 \%$ of global output occurring in West and Central Africa. In Ghana cocoyam is predominantly grown in the wetter forest zones because of its high moisture content requirements for growth. Average yield of cocoyam in Ghana ranges between 4 and 7.5 tons per hectare (MoFA 2011). Yam (Dioscorea $s p$ ) is an annual or perennial climbing plant with edible underground tuber which is native to warmer regions of both southern and northern hemispheres (IITA 2004). A report by IITA indicated that, this tropical-vine tuber is popular in Africa, the West Indies, and parts of Asia, South and Central America (IITA 2004). Yam forms about $10 \%$ of total roots and tubers produced in the World (FAO 2005). Seventy percent $(70 \%)$ of the total yam production in the World comes from Nigeria whilst the rest comes from Côte d'Ivoire, Ghana, Benin, Togo and Cameroon (FAO 2005). Over 600 yam varieties are grown throughout the World, but in West Africa the most economically viable species are the White yam (Dioscorea rotundata), Yellow yam (Dioscorea cayenensis), and Water yam (Dioscorea alata) (Vernier 1998).

Ghana is a net importer of rice and wheat. A report by Ministry of Food and Agriculture Ghana (MoFA 2011) put the consumption of wheat in Ghana at approximately 300,000 MT whiles the estimated per capita consumption stands at $12.5 \mathrm{~kg}$. Almost 80 percent of wheat flour imported into Ghana goes into bread making whiles the remaining 20 percent is used for cakes and other pastries. To curtail the high cost of importation of wheat flour into Ghana, CSIR-Food Research Institute-Ghana under the West Africa Agriculture Productivity Program (WAAPP 2A) has trained bakers and pastry makers on how to use root and tuber and locally grown cereal flour as composite flour for the production of bread and other pastries. These flour are relatively cheaper, easy to produce and could be used in the manufacturing of wide range of products, including bread, cookies, meat pies, cake, chips and doughnut. Composite flour is a percentage blend of any root and tuber or cereal flour and wheat flour. The processes by which these flours are produced may lead to trace metal and aflatoxin contamination. Trace metal and aflatoxin contaminants in foods have become a matter of public health concern in recent times (Aradhna et al. 2009). Trace metals such as copper $(\mathrm{Cu})$, iron (Fe), and zinc $(\mathrm{Zn})$ are essential elements because of their role as cofactors in metabolic and biosynthetic processes. Arsenic (As), lead $(\mathrm{Pb})$ and mercury $(\mathrm{Hg})$ are non-essential for they have no known beneficiary roles and are toxic above certain levels. The essential trace metals may produce toxic effect at high concentrations (Celik and Oehlenschlager 2007; Tuzen 2009). Trace metal accumulate in human organs such as liver, kidney, bone and causes severe health disorders. For instance $\mathrm{Pb}$ can cause renal masses, affect cognitive development and may lead to adult cardiovascular disease (Bandara et al. 2008). Mercury is considered by WHO as one of the top ten chemicals or group of chemicals of major public health concern. Mercury may have toxic effects on the nervous, digestive and immune systems, and on lungs, kidneys, skin and eyes (WHO 2003). For fetuses, infants and children, the primary health effect of mercury is impaired neurological development. Arsenic is also considered as toxic. Ingestion of As leads to gastrointestinal symptoms, and disturbances of cardiovascular and nervous systems functions. Long term exposure to As is casually related to increased risk of cancer (Xiong et al. 2013). Aflatoxin are known to be carcinogenic. Aflatoxin contamination in food is caused by the presence of Asperigillus flavus, Asperigillus nomius and Asperigillus parasitus (Essono et al. 2009). These organism usually contaminate the food product and synthesize the toxins as metabolites in the presence of high levels of carbohydrates and low levels of protein (Essono et al. 2009).

In the present study, the concentrations of trace metal including $\mathrm{As}, \mathrm{Cu}, \mathrm{Fe}, \mathrm{Hg}, \mathrm{Pb}, \mathrm{Zn}$ and aflatoxin $\mathrm{B}_{1}, \mathrm{~B}_{2}, \mathrm{G}_{1}$ and $G_{2}$ were determined in sorghum flour, millet flour, maize flour, rice flour, water yam flour, sweet potato flour and cocoyam flour used as composite flour in bakery and pastry product.

\section{Materials and methods Materials}

Raw sorghum, millet, maize, rice, water yam, sweet potato and cocoyam were bought from Agbogloshie market in Accra, Ghana and transported to the processing laboratory of CSIR-Food Research Institute, Accra for processing into flour.

\section{Methods \\ Sample preparation}

Cocoyam flour preparation: Matured and healthy cocoyam cormels were peeled with sharp stainless steel knife. Peeled cocoyam was washed three times to remove dirt and impurities. The washed peeled cocoyam was sliced into small pieces using the stainless steel knife for easy drying. It was blanched by steeping in hot water for 2-3 minutes and solar dried on thinly cleaned black plastic sheet till it became firm and brittle. Solar dried cocoyam slices were milled using hammer mill and milled flour sifted using sieve to remove lumps to ensure free-flow flour with even particles was obtained. The flour was packaged into sacs lined with moisture-proof polythene and sealed airtight using an electric impulse sealer till 
analysis was carried out (Tortoe et al. 2014). Sweet potato flour and water yam flour were prepared the same way as the cocoyam flour was prepared.

Maize flour preparation: All the three cereal flour samples were prepared using a method by Addo et al. 2015. Mold-free and weevil-free maize was selected. It was poured onto a tray for sorting. Foreign materials such as stones and insect infested maize were removed through winnowing. The maize was dehulled after sorting. The dehulled maize was solar dried on cleaned black plastic polythene sheet until moisture content was about $11 \%$. The dried dehulled maize was milled using hammer mill. The milled flour was sifted using a 250 microns sieve to remove lumps so as to obtain a free-flow flour. The maize flour was then put in sacs lined with moistureproof polythene and sealed with air-tightened electric impulse sealer. The rice flour was prepared the same way as the sorghum flour.

Millet flour preparation: Mold-free and weevil-free millet was selected. Millet grains was poured into a plastic bowl containing enough water. Suspended water millet grain was decanted little at a time using calabash to ensure that millet grains are free of stones and impurities. This process was repeated several times till all stones and impurities are removed from the millet grains. Cleaned millet grains was solar dried by spreading it on a thin black plastic sheet. Millet grains was dehulled and solar dried the second time till moisture content of $11 \%$. The dehulled dried millet was milled into flour using hammer mill. The flour was sifted using a sieve of mesh size of 250 microns to remove all lumps.

Sorghum flour preparation: the variety of sorghum processed was the Beiko peleg which is suitable for the preparation of local food (tuo zaafi). Clean and moldfree sorghum grains was selected for the flour production. Sorghum grains was washed with clean water to remove dirt, stones and other foreign materials. Grain was solar dried by spreading it on a clean black polythene sheet till moisture content was $11 \%$. Grains was dehulled and solar dried for the second time to remove most of the moisture content. It was milled using the hammer mill into flour and sifted using sieve of mesh size of 250 microns to remove lumps.

\section{Chemical analyses}

\section{Trace metal content determination}

The method used by (Ofori et al. 2016) was used for the trace metal analyses. The dry ashing method was used for the Atomic Absorption Spectrometry (AAS) analysis (AOAC 2005). All glass ware was washed with $1 \%$ nitric acid followed by demineralized water. Three grams of each sample was weighed into a platinum crucible. The crucible and test sample was placed in muffle furnace at a temperature of $550{ }^{\circ} \mathrm{C}$ for 8 hours. The crucible with ash was put in desiccator to cool. Five (5) $\mathrm{mL}$ of nitric acid of mass fraction not less than $65 \%$, having a density of approximately $\rho\left(\mathrm{HNO}_{3}\right)=1400 \mathrm{mg} \cdot \mathrm{mL}^{-1}$ was added, ensuring that all the ash came into contact with the acid and the resultant solution heated on hot plate until the ash dissolved. Ten (10) $\mathrm{mL}$ of $0.1 \mathrm{~mol} . \mathrm{L}^{-1}$ nitric acid was added and filtered into $50 \mathrm{~mL}$ volumetric flask. The resultant solution was topped up to the mark with $0.1 \mathrm{~mol} . \mathrm{L}^{-1}$ nitric acid. Blank solution was treated similar as the sample. Buck Scientific 210VGP Flame Atomic Absorption Spectrophotometer (Buck Scientific, Inc. East Norwalk, USA) was used to read the absorbance values at appropriate wavelength of the interested metal in sample solution. Cathode lamps used were As (wavelength $193.7 \mathrm{~nm}$, lamp current $4.0 \mathrm{~mA}$ ), $\mathrm{Cu}$ (wavelength $324.8 \mathrm{~nm}$, lamp current $1.5 \mathrm{~mA}$ ), Fe (wavelength $248.3 \mathrm{~nm}$, lamp current $7.0 \mathrm{~mA}$ ), $\mathrm{Hg}$ (wavelength $253.7 \mathrm{~nm}$, lamp current $0.7 \mathrm{~mA}$ ), $\mathrm{Pb}$ (wavelength $217.0 \mathrm{~nm}$, lamp current $3.0 \mathrm{~mA}$ ), and $\mathrm{Zn}$ (wavelength $213.9 \mathrm{~nm}$, lamp current $2.0 \mathrm{~mA}$ ). The metal content of the sample was derived from calibration graph made up of a minimum of three standards.

\section{Aflatoxins determination}

The extraction procedure used for the determination of aflatoxins was by the Stroka and Anklam (1991). A test portion $(50 \mathrm{~g})$ was extracted with $200 \mathrm{ml}$ methanol/water solvent solution containing $5 \mathrm{~g}$ of sodium chloride. The sample extract was filtered, diluted with phosphate buffered saline to a specified solvent concentration and applied to the immunoaffinity column (R-Biopharm Rhone Ltd. Easi-Extract Aflatoxin) containing antibodies specific for aflatoxins $B_{1}, B_{2}, G_{1}$ and $G_{2}$. Aflatoxins were eluted from the immunoaffinity columns with neat methanol. The Aflatoxin level was quantified by reverse-phase high performance liquid chromatography (RP-HPLC) with post column derivatisation (PCD) involving bromination. The PCD was achieved with pyrimidinum hydrobromide perbromide (PBPB) followed by fluorescence detection. HPLC system used for analyses was from Waters Associates (Milford, MA, USA) and included Waters 1525 Binary HPLC pump, Waters 2707 Autosampler, Waters Model 1500 Column Heater, Waters 2475 Multi $\lambda$ Fluorescence Detector and Breeze 2 software. Separation of the aflatoxin was carried out on a Spherisorb S5 ODS-1 column of dimensions $25 \times 4.6 \mathrm{~mm}$ packed with $5 \mu \mathrm{m}$ particles (phase separation In., Norwalk, USA) maintained at $35{ }^{\circ} \mathrm{C}$. The HPLC mobile-phase flow rate was $10 \mathrm{ml} / \mathrm{min}$ and post column bromine derivatisation of Aflatoxin $B_{1}$, and $G_{1}$ was achieved by PBPB dissolved in $500 \mathrm{ml}$ of demineralised water pumped at a flow rate of $1.0 \mathrm{ml} / \mathrm{min}$ using Elder precision metering pump (Elder laboratories Inc., Sam Carlos, USA). The excitation and emission wave length used were $360 \mathrm{~nm}$ and $440 \mathrm{~nm}$ respectively. The Aflatoxin were identified by means of their retention times, and quantification 
was performed by comparing the peak areas of the samples to those of the standards prepared from pure aflatoxins standard (obtained from R. Biopharm) solutions under identified conditions.

\section{Quality control of results}

Samples were handled carefully to avoid contamination as part of measure to ensure reliability of results. The recovery test of the total analytical procedures was also carried out for the metals analyzed in the selected samples by spiking analyzed samples with aliquots of metal standards and then reanalyzed the samples. Acceptable recovery ranges of $94 \pm 1$ to $95 \pm 1 \%, 96 \pm 1$ to $97 \pm 1 \%$, $93 \pm 1$ to $95 \pm 1 \%, 93 \pm 1$ to $94 \pm 1 \%, 95 \pm 1$ to $96 \pm 1 \%$, $95 \pm 1$ to $97 \pm 1 \%$ were obtained for $\mathrm{As}, \mathrm{Cu}, \mathrm{Fe}, \mathrm{Hg}, \mathrm{Pb}$ and $\mathrm{Zn}$ respectively.

\section{Data analysis}

The standard deviations on mean values of duplicate samples were analyzed using Statistical Package for Social Scientist (SPSS 2013), version 21. Analyses of Variance (ANOVA), Duncan test was used to compare the means.

\section{Results and discussion}

\section{Trace metal analyses}

Trace metal variation of root and tuber flour is shown in Table 1. There was no significant differences in the concentration of As determined in all the three root and tuber flour samples at $p<0.05$. WHO has recommended Provisional Tolerable Weekly Intake (PTWI) of As as $0.015 \mathrm{mg} / \mathrm{Kg}$ body weight (WHO 2010). The maximum concentration of As determined in the root and tuber flour was $<0.01 \mathrm{mg} / \mathrm{Kg}$ which is below the recommended PTWI by WHO. The minimum and maximum $\mathrm{Cu}$ concentration determined in the root and tuber flour was $0.69 \pm 0.01 \mathrm{mg} / \mathrm{Kg}$ and $3.67 \pm 0.02 \mathrm{mg} / \mathrm{Kg}$, respectively which are far below the limit of $40 \mathrm{mg} / \mathrm{Kg}$ limit set by WHO as limit of $\mathrm{Cu}$ in foods (WHO 1982). Fe deficiency anemia affect one-third of the World population. However, excess intake of $\mathrm{Fe}$ causes colorectal cancer (Senesse et al. 2004). The concentration of Fe determined in root and tuber ranged from $10.97 \pm 0.01 \mathrm{mg} /$ $\mathrm{Kg}$ to $27.64 \pm 0.16 \mathrm{mg} / \mathrm{kg}$ with the highest concentration above the $15 \mathrm{mg} / \mathrm{Kg}$ limit set by WHO as limit of Fe in food (WHO 1982). The maximum concentrations of $\mathrm{Hg}$ and $\mathrm{Pb}$ determined in root and tuber flour was $<$ $0.01 \mathrm{mg} / \mathrm{Kg}$ and $0.02 \pm 0.01 \mathrm{mg} / \mathrm{Kg}$ respectively. Impairment related to $\mathrm{Hg}$ toxicity includes peripheral vision, disturbances in sensations, muscle weakness and lack of movement coordination (Xiong et al. 2013). WHO has recommended a Provisional Tolerable Weekly Intake (PTWI) of $\mathrm{Hg}$ as $1.6 \mu \mathrm{g} / \mathrm{Kg}$ body weight (WHO 2003). $\mathrm{Pb}$ is toxic even at trace levels (Dobaradaren et al. 2010). The maximum $\mathrm{Pb}$ concentration determined in root and tuber was below the $10 \mathrm{mg} / \mathrm{Kg}$ limit set by WHO as limit of $\mathrm{Pb}$ in raw plant material (WHO 1982). The concentration of $\mathrm{Zn}$ determined in root and tuber flour ranged from $6.79 \pm 0.01 \mathrm{mg} / \mathrm{Kg}$ to $15.54 \pm 0.52 \mathrm{mg} / \mathrm{Kg}$, which are below the $60 \mathrm{mg} / \mathrm{Kg}$ limit that has been set by WHO (WHO 1982).

Table 2 shows the variation in trace metal concentration of cereal flour samples. The maximum concentration of $\mathrm{As}, \mathrm{Cu}, \mathrm{Fe}, \mathrm{Hg}, \mathrm{Pb}$ and $\mathrm{Zn}$ in the cereal flour samples were $<0.01, \quad 3.07 \pm 0.01, \quad 201.40 \pm 0.14,<0.01$, $0.05 \pm 0.01,34.36 \pm 0.06 \mathrm{mg} / \mathrm{Kg}$ respectively; of which the concentrations of $\mathrm{As}, \mathrm{Cu}, \mathrm{Hg}, \mathrm{Pb}$ and $\mathrm{Zn}$ fell below the WHO set limit whilst that of Fe happens to be far above the WHO set limit (WHO 1982).

Table 3 compares trace metal concentrations in Sweet potato flour, cocoyam flour, water yam flour, sorghum flour, rice flour, maize flour and millet flour. The trace metal concentration of essential metals such as $\mathrm{Cu}, \mathrm{Fe}$ and $\mathrm{Zn}$ in all the seven flour samples ranged from 0.03 \pm 0.01 to $6.63 \pm 0.02,10.97 \pm 0.01$ to $201.40 \pm 0.14$, and $6.04 \pm 0.03$ to $34.36 \pm 0.06 \mathrm{mg} / \mathrm{Kg}$ respectively. According to Silvestre et al. $2000 \mathrm{Cu}$ is essential constituent of some metalloenzymes and is required for haemoglobin synthesis and in the catalysis of metabolic growth. The highest concentration of $\mathrm{Cu}$ determined in all the seven flour samples was $6.63 \pm 0.02 \mathrm{mg} / \mathrm{Kg}$ which is far below the $40 \mathrm{mg} / \mathrm{Kg}$ limit that has been set by WHO (WHO 1982) as limit of $\mathrm{Cu}$ in foods. Statistically, there was no significant differences in the concentration of $\mathrm{Cu}$ in Sorghum and Millet flour which are cereals grown in the northern part of Ghana. Fe is also essential metal for the body but excess intake may lead to colorectal cancer (Senesse et al. 2004). The concentration of Fe determined in Cocoyam flour, Sorghum flour, Maize flour and Millet flour were above the $15 \mathrm{mg} / \mathrm{Kg}$ limit set by WHO as limit of Fe in Foods (WHO 1982). Ma and Betts (2000) stated that $\mathrm{Zn}$ constitutes about $33 \mathrm{ppm}$ of

Table 1 Variations in trace metal concentration in $\mathrm{mg} / \mathrm{Kg}$ dried weight of root and tuber flour

\begin{tabular}{llllllr}
\hline Sample & As & $\mathrm{Cu}$ & $\mathrm{Fe}$ & $\mathrm{Hg}$ & $\mathrm{Pb}$ & $\mathrm{Zn}$ \\
\hline Sweet potato flour & $<0.01^{\mathrm{a}}$ & $0.69 \pm 0.01^{\mathrm{a}}$ & $10.97 \pm 0.01^{\mathrm{a}}$ & $<0.01^{\mathrm{a}}$ & $<0.01^{\mathrm{a}}$ & $6.79 \pm 0.01^{\mathrm{a}}$ \\
Cocoyam flour & $<0.01^{\mathrm{a}}$ & $6.63 \pm 0.02^{\mathrm{b}}$ & $27.64 \pm 0.16^{\mathrm{b}}$ & $<0.01^{\mathrm{a}}$ & $<0.01^{\mathrm{a}}$ & $15.54 \pm 0.52^{\mathrm{b}}$ \\
Water yam flour & $<0.01^{\mathrm{a}}$ & $3.67 \pm 0.02^{\mathrm{c}}$ & $15.11 \pm 0.06^{\mathrm{c}}$ & $<0.01^{\mathrm{a}}$ & $0.02 \pm 0.01^{\mathrm{a}}$ & $9.19 \pm 0.04^{\mathrm{c}}$ \\
\hline
\end{tabular}

Results are presented as means \pm standard deviation. Superscript to figures in the same column implies significant or insignificant differences at $p<0.05$ (ANOVA, Duncan test) 
Table 2 Variations in trace metal concentration in $\mathrm{mg} / \mathrm{Kg}$ dried weight of cereal flour

\begin{tabular}{llllllr}
\hline Sample & As & $\mathrm{Cu}$ & $\mathrm{Fe}$ & $\mathrm{Hg}$ & $\mathrm{Pb}$ & $\mathrm{Zn}$ \\
\hline Sorghum flour & $<0.01^{\mathrm{a}}$ & $2.77 \pm 0.33^{\mathrm{a}}$ & $116.75 \pm 0.07^{\mathrm{a}}$ & $<0.01^{\mathrm{a}}$ & $<0.01^{\mathrm{a}}$ & $25.36 \pm 0.06^{\mathrm{a}}$ \\
Rice flour & $<0.01^{\mathrm{a}}$ & $1.09 \pm 0.05^{\mathrm{b}}$ & $11.87 \pm 0.06^{\mathrm{b}}$ & $<0.01^{\mathrm{a}}$ & $<0.01^{\mathrm{a}}$ & $7.84 \pm 0.01^{\mathrm{b}}$ \\
Maize four & $<0.01^{\mathrm{a}}$ & $0.03 \pm 0.01^{\mathrm{c}}$ & $20.44 \pm 0.02^{\mathrm{c}}$ & $<0.01^{\mathrm{a}}$ & $<0.01^{\mathrm{a}}$ & $6.04 \pm 0.03^{\mathrm{c}}$ \\
Millet flour & $<0.01^{\mathrm{a}}$ & $3.07 \pm 0.01^{\mathrm{a}}$ & $201.40 \pm 0.14^{\mathrm{d}}$ & $<0.01^{\mathrm{a}}$ & $0.05 \pm 0.01^{\mathrm{b}}$ & $34.36 \pm 0.06^{\mathrm{d}}$ \\
\hline
\end{tabular}

Results are presented as means \pm standard deviation. Superscript to figures in the same column implies significant or insignificant differences at $p<0.05$ (ANOVA, Duncan test)

adult body weight and is essential as a constituent of many enzymes involved in a number of physiological functions such as protein synthesis and energy metabolism. Zinc deficiency has been linked to increased risk of stunting in children (Black et al. 2008). The minimum and maximum $\mathrm{Zn}$ concentrations determined in the cereal and root and tuber flour were below the limit of $60 \mathrm{mg} / \mathrm{Kg}$ set by WHO (WHO 1982). The highest concentrations of $\mathrm{As}, \mathrm{Hg}$ and $\mathrm{Pb}$ determined in the seven flour samples were $<0.01,<0.01$, and $0.05 \pm 0.01 \mathrm{mg} / \mathrm{Kg}$ respectively which were all below the WHO set limit of $\mathrm{As}, \mathrm{Hg}$ and $\mathrm{Pb}$ in foods. The maximum concentration of $\mathrm{Hg}$ determined in the root and tuber and cereal flour samples was $<0.01 \mathrm{mg} / \mathrm{Kg}$ which is similar to that determined in cassava flour samples by Ofori et al. (2016). Arsenic (As) and $\mathrm{Pb}$ was not detected in processed cassava flour samples analyzed in Ghana by Ofori et al. (2016) but was detected in all the root and tuber and cereal flour sample analyzed presently even though their concentrations were within acceptable levels by WHO (WHO 1982).

\section{Aflatoxin analyses}

The recovery of the analytical method was $90.50,76.56$, $95.58,91.76 \%$ for aflatoxin $B_{1}, B_{2}, G_{1}$, and $G_{2}$ respectively and a linearity of $R^{2}=0.999$. The seven flour samples of Maize, Sorghum, Millet, Rice, water Yam, Cocoyam and Potato did not contain aflatoxin $B_{1}, B_{2}, G_{1}$ and $G_{2}$ at detectable levels, which may be attributed to good processing techniques used. The limit of detection (LOD) for aflatoxin $B_{1}$ and $B_{2}$ was $0.15 \mu \mathrm{g} / \mathrm{kg}$ and aflatoxin $G_{1}$ and $G_{2}$ was $0.13 \mu \mathrm{g} / \mathrm{kg}$ whiles the limit of quantification (LOQ) for aflatoxin $B_{1}, B_{2}, G_{1}$, and $G_{2}$ was $0.16,0.30,0.28$ and $1.08 \mu \mathrm{g} / \mathrm{kg}$, respectively. Limit of detection (LOD) and LOQ for aflatoxin was obtained using the formula; LOD = standard concentration at which no peak was observed (3*baseline noise/peak height) and $\mathrm{LOQ}=2^{*} \mathrm{LOD}$. The findings from the present work conforms to a similar work on aflatoxins content in High Quality Cassava Flour (HQCF) done by Ofori et al. (2016) where aflatoxin $B_{1}, B_{2}, G_{1}$, and $G_{2}$ was not detected in all HQCF samples analyzed but contradict previous studies on aflatoxin determination in Maize, Sorghum, Millet and Water yam flour in some West African countries such as Ghana, Gambia and Nigeria. For example Kpodo (2001) conducted aflatoxin determination in maize from Ghana which revealed that eighty-four (84) out of one hundred and twenty-eight (128) maize kernel sampled from markets and maize processing sites were contaminated with aflatoxin at level up to $200 \mathrm{ng} / \mathrm{g}$ whiles a similar studies on aflatoxin determination in cereal-based food products intended for infants and young children done by Blankson and Mill-Robertson (2016) also showed aflatoxin contamination at levels of $0.18 \pm 0.01$ to $36.10 \pm 0.32 \mu \mathrm{gkg}^{-1}$. Hudson et al. (1992)) analyzed nine millet samples for aflatoxin in Gambia a West African country and all the nine sample were contaminated with aflatoxin to level ranging from 1-27 ng/g. Gbolagade et al. (2011) in Nigeria analyzed six yam flour samples which were all contaminated with aflatoxins to a level ranging from $25.17 \mu \mathrm{g} / \mathrm{kg}$ to $32.33 \mu \mathrm{g} / \mathrm{kg}$.

Table 3 Variations in trace metal concentration in $\mathrm{mg} / \mathrm{Kg}$ dried weight of cereal and root and tuber flour

\begin{tabular}{|c|c|c|c|c|c|c|}
\hline Sample & As & $\mathrm{Cu}$ & $\mathrm{Fe}$ & $\mathrm{Hg}$ & $\mathrm{Pb}$ & $\mathrm{Zn}$ \\
\hline Sweet potato flour & $<0.01^{\mathrm{a}}$ & $0.69 \pm 0.01^{a}$ & $10.97 \pm 0.01^{\mathrm{a}}$ & $<0.01^{a}$ & $<0.01^{a}$ & $6.79 \pm 0.01^{a}$ \\
\hline Cocoyam flour & $<0.01^{\mathrm{a}}$ & $6.63 \pm 0.02^{b}$ & $27.64 \pm 0.16^{b}$ & $<0.01^{a}$ & $<0.01^{\mathrm{a}}$ & $15.54 \pm 0.52^{b}$ \\
\hline Water yam flour & $<0.01^{a}$ & $3.67 \pm 0.02^{c}$ & $15.11 \pm 0.06^{c}$ & $<0.01^{a}$ & $0.02 \pm 0.01^{a}$ & $9.19 \pm 0.04^{c}$ \\
\hline Sorghum flour & $<0.01^{\mathrm{a}}$ & $2.77 \pm 0.33^{d}$ & $116.75 \pm 0.07^{d}$ & $<0.01^{a}$ & $<0.01^{\mathrm{a}}$ & $25.36 \pm 0.06^{d}$ \\
\hline Rice flour & $<0.01^{\mathrm{a}}$ & $1.09 \pm 0.05^{e}$ & $11.87 \pm 0.06^{\mathrm{e}}$ & $<0.01^{\mathrm{a}}$ & $<0.01^{\mathrm{a}}$ & $7.84 \pm 0.01^{e}$ \\
\hline Maize flour & $<0.01^{a}$ & $0.03 \pm 0.01^{f}$ & $20.44 \pm 0.02^{f}$ & $<0.01^{\mathrm{a}}$ & $<0.01^{\mathrm{a}}$ & $6.04 \pm 0.03^{f}$ \\
\hline Millet flour & $<0.01^{\mathrm{a}}$ & $3.07 \pm 0.01^{d}$ & $201.40 \pm 0.14^{9}$ & $<0.01^{\mathrm{a}}$ & $0.05 \pm 0.01^{b}$ & $34.36 \pm 0.06^{9}$ \\
\hline
\end{tabular}

Results are presented as means \pm standard deviation. Superscript to figures in the same column implies significant or insignificant differences at $p<0.05$ (ANOVA, Duncan test) 


\section{Conclusion}

The maximum concentration of essential metal, $\mathrm{Cu}$ and $\mathrm{Zn}$ determined in the cereal and root and tuber flour samples was $6.63 \pm 0.02 \mathrm{mg} / \mathrm{Kg}$ and $34.36 \pm 0.06 \mathrm{mg} / \mathrm{Kg}$ respectively which are below the WHO set limits and therefore pose no health threat. The highest Fe concentration determined in the flour samples was $201.40 \pm$ $0.14 \mathrm{mg} / \mathrm{Kg}$ which is far above the WHO set limit and therefore pose a health threat. The toxic metals: As, $\mathrm{Hg}$ and $\mathrm{Pb}$ had their concentrations below the WHO set limit and therefore pose no health threat. Aflatoxin $B_{1}$, $B_{2}, G_{1}$ and $G_{2}$ were not detected in all the cereal and root and tuber flour samples analyzed and hence pose no health threat.

\section{Acknowledgement}

This is an output from the West Africa Agriculture Productivity Program (WAAPP 2A)-Ghana, funded by the World Bank and Government of Ghana. The views expressed are not necessarily those of World Bank.

\section{Authors' contributions}

The work was done in collaboration between all authors. Authors $\mathrm{HO}$ and CT designed the experiment. Author $\mathrm{HO}$ conducted the experiments. Authors $H O, C T, P T A$ and JA conducted the literature search, performed the statistical analyses and wrote the first draft of the manuscript. All authors read and approved the final draft of the manuscript.

\section{Competing interests}

The authors declare that they have no competing interests.

Received: 23 July 2016 Accepted: 23 September 2016

Published online: 29 September 2016

\section{References}

Addo P, Tortoe C, Hagan L, Buckman ES, Akonor PT, Padi A, Addy P, Dawson AE, Wayo TC. Indigenous Cereal Composite Flour Processing and Recipe Training Manual. Accra: Council for Scientific and Industrial Research-Food Research Institute; 2015. p. 15-50.

AOAC. Official methods of analysis of AOAC International. 18th ed. Gaithersburg: AOAC International; 2005.

Aradhna G, Devendra KR, Ravi SP, Bechan S. Analysis of some heavy metals in the riverine water, sediments and fish from Ganges at Allahabad. Environ Monit Assess. 2009:157:449-58.

Bandara JMRS, Senevirathna DMAN, Dasanayake DMRS, Herath V, Bandara JMRP, Abeysekara T, et al. Chronic renal failure among farm families in cascade irrigation systems in Sri Lanka associated with elevated dietary cadmium levels in rice and freshwater fish (Tilapia). Environ Geochem Health. 2008;30:465-78.

Black, Caulfield LE, De Onis M, Ezzati M, Mathers C, Rivera J. Maternal and child undernutrition: global and regional exposures to health consequences. Lancet. 2008:371:243-60.

Blankson GK, Mill-Robertson FC. Aflatoxin contamination and exposure in processed cereal-based complementary foods for infants and young children in greater Accra, Ghana. Food Control. 2016;64:212-7.

Celik U, Oehlenschlager J. High of cadmium, lead, zinc and copper in popular fishery products sold in Turkish supermarkets. Food Control. 2007;18(3):258-61.

Dobaradaren S, Kaddafi K, Nazmara S, Ghaedi H. Heavy metals (Cd, Cu, Ni, and $\mathrm{Pb}$ ) content in fish species of Persian Gulf in Bushehr Port, Iran. AJ Biotech. 2010;32:6191-3.

Essono G, Ayodele M, Akoa A, Foko J, Filtengborg O, Olembo S. Aflatoxinproducing Aspergillus spp and aflatoxin levels in stored cassava chips as affected by processing practices. Food Control. 2009;20:648-54.

FAO. FAOSTAT Agriculture data. Food and Agriculture Organisation of the United Nations. 2005.

FAO. Food and Agricultural Organization (FAO) production statistics. 2012.

Gbolagade J, Ibironka A, Yetunde O. Nutritional composition, fungi and aflatoxins detection in stored "gbodo" (fermented Dioscorea rotundata) and "elubo ogede" (fermented Musa parasidiaca) from South-western Nigeria. Afr J Food Sci. 2011:5(2):105-10.

Hudson GJ, Wild CP, Zarba A, Groopman JD. Aflatoxin isolated by immunoaffinity chromatography from foods consumed in The Gambia, West Africa. Nat Toxins. 1992;1:100-5.

IITA. International Institute of Tropical Agriculture. Nigerian's Cassava Industry: Statistical Handbook. 2004.

Kpodo KA. Fusaria and Fumonisins in maize and fermented maize products in Ghana. PhD. Thesis. University of Ghana, Legon, Ghana. 2001.

Kudadjie CY, Struik PC, Richards P, Offei SK. Assessing production constraints, management and use of sorghum diversity in North-East Ghana: A diagnostic study. University of Ghana, Legon Accra, University of Wageningen; 2004.

Ma J, Betts NM. Zinc and Copper intakes and their major food sources for older adults in the 1994-96 continuing survey of food intakes by individual 9CSF-II). J Nutr. 2000;130:2838-43.

MoFA. Agriculture in Ghana, Facts and Figures, 2011. Statistical Research and Information Directorate (SRID). Ghana Ministry of Food and Agriculture; 2012.

Ofori $\mathrm{H}$, Akonor PT, Dziedzoave NT. Variation in trace metal and aflatoxin content during processing of High Quality Cassava Flour (HQCF). Int J Food Contam. 2016;3:1.

Onyeka J. Status of cocoyam (Colocasia esculanta and Xanthosoma spp) in West and Central Africa: Production, Household Importance and Threat from Leaf Blight. Lima (Peru).CGIAR Research Program on Roots, Tubers and Bananas (RTB). 2014. www.rtb.cgiar.org

Senesse P, Meance S, Cottet V, Faivre J, Boutron-Ruault MC. High dietary iron and copper and risk of colorectal cancer: a case -control study in Burgundy, France. Nutr Cancer. 2004:49:66-71.

Silvestre MD, Lagarda MJ, Farra R, Martineze-Costa C, Brines J. Copper, iron and zinc determination in human milk using FAAS with microwave digestion. Food Chem. 2000:68:95-9.

SPSS 21 for Windows (2013). SPSS 21 for Windows. Chicago, Illinois, USA. Stroka J, Anklam E. Quantitative analysis for aflatoxins. JAOAC. 1991;74:81-4.

Tortoe C, Akonor PT, Padi A, Boateng C, Opoku Asiama M, Addy P, Dawson AE, Wayo TCA. Root and Tuber Composite Flour Processing and Recipe Manual. Accra: Council for Scientific and Industrial Research-Food Research Institute; 2014. p. 3-24.

Tuzen M. Toxic and essential trace elemental contents in fish species from Black Sea, Turkey. Food Chem Toxicol. 2009;47(8):1785-90.

Vernier P. Yam chips production in West Africa. The newsletter of post-harvest system in Africa. International Institute of Tropical Agriculture. No. 2, 1998.

World Health Organisation (WHO). Evaluation of Certain Foods Additives and Contaminants (Twenty-Six Report of the Joint FAO/WHO Expert Committee on Food Additives). WHO Technical Report series, No. 683, Geneva; 1982.

World Health Organisation (WHO). Evaluation of certain food additives and contaminants (sixty-first report of the joint FAO/WHO expert committee on food additives). WHO technical report series, No. JECFA/16/SC, Rome; 2003.

World Health Organisation (WHO). Evaluation of certain food additives and contaminants (sixty-first report of the joint FAO/WHO expert committee on food additives). WHO technical report series, No. JECFA/72/SC, Rome; 2010.

Xiong C, Zhang Y, Xu X, Lu Y, Ouyang B, Ye Z, et al. Lotus roots accumulate heavy metals independently from soil in main production regions of China. Scientia Horticulturea. 2013;164:295-302.

\section{Submit your manuscript to a SpringerOpen ${ }^{\odot}$ journal and benefit from:}

- Convenient online submission

- Rigorous peer review

- Immediate publication on acceptance

- Open access: articles freely available online

- High visibility within the field

- Retaining the copyright to your article

Submit your next manuscript at $>$ springeropen.com 